\title{
SUPPLY CHAIN MANAGEMENT PRACTICES FOR SMES
}

\author{
Vivien Kerekes $^{1}$, János Felföldi ${ }^{2}$ \\ ${ }^{1}$ University of Debrecen, Faculty of Economics and Business \\ Institute of Applied Informatics and Logistics \\ Hungary, 4032 Debrecen Böszörményi Str. 138. \\ ${ }^{2}$ University of Debrecen, Faculty of Economics and Business \\ Institute of Applied Informatics and Logistics \\ Hungary, 4032 Debrecen Böszörményi Str. 138. \\ ${ }^{1}$ vivien.kerekes@gmail.com \\ 2felfoldi.janos@econ.unideb.hu
}

\begin{abstract}
In today's globalized business environment small and medium sized enterprises (SMEs) face many challenges. In order of their survival SMEs need to produce more, at a lower cost, in less time, and with a few defects. They form the most significant group of manufacturing firms and give supports to large companies in many supply chains. In addition, SMEs contribute greatly to entrepreneurship, gross domestic product (GDP) and employment. Despite the fact that micro, small and medium sized enterprises have very important role in business networks, they still have many problems with using supply chain management (SCM) practices. In this research my purpose was to find the best SCM practices as a strategic method to improve SMEs' performance. First, I give information in general about SCM and the SMEs, then highlight main characteristics of small firms compared to large ones and the reasons why it is essential and efficient to use SCM practices. The article is based on secondary data, using several analysis, surveys, books, journals and my personal experiences collected in this sector. I conclude the research by summarizing my recommendations in connection with SCM practices, the opportunities and barriers.
\end{abstract}

Keywords: SMEs, supply chain management - SCM, competitiveness, efficiency, business

(JEL code: $M 11$ )

\section{INTRODUCTION}

Small and medium sized enterprises (SMEs) have important role in contributing to economic development and employment generation in emerging and developing countries. Nowadays, the SME sector can be characterized by three essential factors, like dynamism, innovation and flexibility ( $\mathrm{KOH}$ et. al. 2007). Micro, small and mediumsized companies play a central role in the Hungarian economy, too. They are a major source of entrepreneurial skills, innovation and employment. They have difficulties usually in the early start-up phase in obtaining capital or credit. On the other hand, their restricted resources reduce access to new technologies and innovation (SZIRA, 2014). According to my experiences the importance of small companies is indisputable as they have essential role in job creation, production and especially in local services. Small firms are usually powerful founded on original idea, fast-growing ones. On the one hand SMEs are founded in large-scale, but on the other hand they usually disappear rapidly as they are in many cases for self-employed. SMEs comprise about 80 per cent of enterprises in most emerging countries, and as a result they make a large contribution to entrepreneurship, gross domestic product and employment. Several researchers confirmed that small firms have remarkable impacts on supply chain performance 
as they operate as suppliers, producers, distributors and customers. Other researchers stated that SMEs usually act as the first and second tier suppliers in the larger companies' supply chain. Therefore, their essential role is obvious in contributing to employment and economic growth, so small and medium sized companies form the most significant group of manufacturing firms (BAYMOUT, 2015). Additionally, in spite of the fact that small organizations now have important role in global business environment, they still face supply chain inefficiency. In this article my main aim is to find out how supply chain management (SCM) may contribute to the success of SMEs, what parts of supply chain management take part mostly in the operations of small enterprises. To achieve my main purpose I needed to set up sub-objectives:

- summarizing the concept of supply chain management,

- collecting the most important characteristics of SMEs compared to large companies,

- gathering the enablers, barriers to successful supply chain implementation and their effects on SMEs.

My research is based on literature review and personal experiences on supply chain management practices.

In these days business environment and global marketplace are characterized by competitiveness where the survival and increase of SMEs is not easy. Customers have more demands to get high quality products at a lower price, better services, wider product range and quick distribution (CHOW et. al. 2008; KETCHEN et. al. 2008). In my opinion all the above mentioned characteristics determine the day-today operations of small ones that cause many difficulties and challenges for them. Additionally, many changes in business models create many problems for businesses to survive. Lower production cost, delivery of ever-increasing customer value, flexibility with superior service and the impact of information technology are creating problems for organizations to survive (CHANDRA and KUMAR 2000). The above mentioned challenges make cross-boundary relationships between business partners inevitable. As a result of these emerging situations many companies have identified the fact that nowadays individual firms are pushed into the backgrounds and creating supply chain networks is the base of their success (LI et. al. 2005; KOH et. al. 2007; CHOW et. al. 2008). Thus companies can no longer effectively compete in isolation of their suppliers and other partners in the supply chain (LUMMUS and VOKURKA 1999). It has become essential to look for partnerships and useful information links with trading entities, so it is advisable to stop the traditional boundaries of firms. SCM proved to be one of the most effective tools to achieve competitive advantage (LI et. al. 2005; KETCHEN et. al. 2008). As I see small companies compared to large ones manage fewer resources, operate fewer processes and activities, and produce less on a narrower palette. All these characteristics allow the small ones a flat organizational structure thus communication and decision-making can be faster and more efficient. Small businesses are characterized by close and informal working relationships, operation is less formalized, employees' work satisfaction is higher, family atmosphere is more typical. These characteristics make possible the SMEs a kind of flexibility. Corporate innovation processes are supported by this flexibility and as a result of this many new valuable ideas are created in small businesses useful for big ones, too. In summary the cooperation and interdependence of small ones and large companies should be obvious.

Supply chain management is a network consisting of every participant included directly or indirectly in the chain. The network involves manufacturer, supplier, retailer and customer. The whole system includes production and delivery of products or services to final customers both in upstream and downstream parts (MENTZER et. al. 2001) over physical delivery, information flow and budget (STOCK and BOYER 2009). According to Mentzer and other authors one of the purposes of SCM is to develop the long-term performance of individual companies and thus the supply chain as a whole (MENTZER et. al. 2001). According to another assumption supply chain management is a comprehensive approach to demand, sourcing, procurement, production and logistics process management (CHOW et. al. 2008). As THOO et. al. (2012) define: supply chain management is going through a kind of revolution (MELNYK et al. 2009) and developing rapidly; new SCM concepts include differences in strategies, increase in value, development regarding operational efficiency, cost reduction (BIDGOLI, 2010), SC union and working together, operational greatness and potential supply chains (CHOW et. al. 2008). The concept of supply chain management has grown fast. To reach the best level of performance needed focusing on supplier (LUMMUS and VOKURKA, 1999) and customer (LAGROSEN, 2005). European small and medium sized companies realized that through collaborative relationships they can acquire many benefits of integrated supply chain (MUDAMBI et. al. 2004; MEEHAN and MUIR 2008). Integrated supply chain can drive to outstanding modifications in the operation of businesses, in their processes, improves services in quality, reduces cost and results efficiency (APO, 2002). However, many Hungarian SMEs understand the essence of SCM but micro and small companies still lack of practicing effective SCM concepts. It has many reasons like weak supplier network, absence of knowledge on SCM and lack of exact management duties. It is obvious that Hungarian SMEs, especially micro and small-sized businesses will have more difficulties with the implementation of supply chain management than big companies. It can be observed during the process of managing and responding to the expanded system of markets, technologies and suppliers.

Small and medium sized enterprises have strengths and weakness as well. Small businesses can be characterized by the followings: they are flexible, can make decisions quickly, and cooperate with employees. Their weak points are the followings: they do not have enough technical superiority, infrastructural facility and financial resource (DANGAYACH and DESHMUKH 2001). There are three 
important factors between small and big companies they differ from each other: uncertainty, innovation and evolution. The advantages of SMEs seem to be behavioural, stressing qualitative differentiation and innovation (O'GORMAN, 2001). Compared to large firms SMEs are characterized by having only a few products, a few customers and low volume. They lack experiences and learning capacity, they are bounded rational, have higher capital and transaction costs, have a reactive nature, technologically focused with weak marketing skills, have limited resources and high strategic reliance on CEO perceptions of market forces and generally are more vulnerable (COVIELLO and McAULEY 1999; O'GORMAN, 2001). So small firms usually do not employ SCM, they are managed by the needs of significant customers (QUAYLE, 2003), that I can confirm based on my experiences spent in the SMEs sector.

\section{MATERIALS AND METHODS}

I used literature review to collect information in connection of use of SCM practices regarding small and medium sized businesses. Many international books, journals contributed to the results of this article. One of the purposes of this paper was to explore the utility of SCM for SME sector. Important questions focusing in this article: How supply chain management can help micro, small and medium sized enterprises to enhance business performance and how the supply chain management can differ small firms compared to big companies? This paper provides a short insight to these topics that makes possible further researches.

\section{RESULTS AND DISCUSSION}

According to my first sub-objective, the idea of supply chain management regarding SMEs is an approach that supports the company to operate in a more agile and cost effective method by integrating the processes of different partners at all three levels - strategic, tactical, and operational. Even though globalization has increased pressure on a few small firms to constantly decrease their prices against their quality and services, SCM can make better the performance of SMEs and enhance their profitability by improving their ability to get supplies of the right quality, at the right time, and at the most favoured prices (BAYMOUT, 2015). As far as I know a comprehensive cooperation between small firms could help the operation and the everyday work of the individual ones.

For SMEs supply chain integration is very difficult. It refers to the integration of internal processes with the external supply chain network that can be implemented with communication, partnerships, alliances and cooperation (HANDFIELD and NICHOLS 1999). The most important elements of supply chain integration are cooperation, collaboration, information sharing, trust, partnerships, shared technology and a fundamental shift away from managing individual functional processes to managing integrated chains of processes (AKKERMANS et. al. 1999). The integration of logistic activities with other functional areas can give also competitive advantage (GUNASEKARAN and NGAI 2003). It can reduce operational costs and improve customer services (RICHARDSON, 1995). SCM has positive and negative effects on the performance of small firms. On the one hand, SCM can contribute to better quality, cost reduction, higher customer service, leverage and risk reduction benefits for SMEs. On the other hand, SCM exposes smaller companies to greater management and control hazards while diminishing its private differentiation advantages (AREND and WINSER 2004). According to the most important elements of supply chain integration, partnership is one of the most significant factor in problem solving that can improve supply chain partners' knowledge and learning experience, too. In addition, longstanding and effective partnerships between organizations require many factors, such as the ability of collaboration in terms of culture, procedures, working practices, frequent communication, and the need to keep track of technological and other developments taking place outside of the relationship. Small firms' alliance and network activity may help the SMEs overcome size and resource constraints with better innovation and lower costs and uncertainties. Regarding information sharing it is one the most critical drivers between partners to establish trust. The problem is that many partners do not want to share commercially sensitive data (BAYMOUT, 2015).

As for my second sub-objective regarding the most important characteristics of SMEs compared to large companies, in general for SME sector is very important to give the right product to the right customers at the right cost, right time, right quality and right quantity according to supply chain management concepts (BASHER, 2010). Due to another approach small businesses can differentiate their products and services with superior features, like high quality and high customer service (PORTER, 1985). There are differences in short-term strategic and long-term goals of SCM. The short-term goals include reducing cycle time and inventory thus increasing productivity, while longterm goal is to increase profits through market share and customer satisfaction (TAN, 2002). A well-functioning SCM has many advantages like lower supply chain costs, overall productivity, inventory reduction, forecast accuracy, delivery performance, fulfilment cycle time and fill rates (MOHANTY and DESHMUKH 2005). In contrary to large enterprises, SMEs can be characterized by unbalanced structure and less management levels thus all the duties and responsibilities are centred upon the leader's hands. All these characteristics make SMEs' organizational culture easier to change (GOUROVA, 2010), minimize the communication line within and across the teams (ARAGON-CORRERA et. al. 2008) and strengthen efficient and informal communications (LEVY et. al. 2001). On the other hand, according to the SMEs' organizational structure they have the advantage to initiate and implement changes easily, so the flat organizational structure of small businesses can simplify the changes of supply chain management implementation, too. Despite the fact that SMEs are facing with complexity and uncertainty, usually they 
are good at making new things and growth. According to a study SMEs have more innovations (twice per employee) than have large companies (ACS and AUDRETSCH 1991). SMEs are often important partners of big companies due to their dynamism. The two mostly dependent industries are the FMCG that is called fast moving consumer goods and the automobile industry. This feature makes them possible to contribute to development in economy. Their smaller size makes them possible to be flexible in adapting new ways how they carry out their duties and finding out new solutions for it. Actually, small firms can solve the problems deriving from their size limits with using lots of creativity in their products and services through research and development (EBRAHIM et. al. 2008). Many small enterprises are ready to use new and not tested technologies that is crucial to boost dynamic efficiency within SME sector (ADB, 2009). In addition, smaller enterprises can adapt quickly to the ever-changing market conditions and they are more active in their internal operations (LAZARICA, 2009). SMEs can adjust quickly to the demand and market changes with SCM implementation. In general SMEs have fewer customers (THAKKAR et. al. 2009). Another way for smaller firms to be successful is to create closer and long lasting relationships with their customers and then make it more personal (HONG and JEONG 2006). SME sector is characterized by a few major and stronger customer (PITTAWAY and MORRISSEY 2004). Also in Hungary small firms try to develop a longterm relationship with their customers. SMEs often depend on their suppliers' relationship if they have. Small firms have problems with resources in terms of raw materials, financial, skills, knowledge and technology. So suppliers help to connect internal and external capabilities of the smaller firms. As their customer relationships are featured by close and long lasting contacts, they try to build deep suppliers relationships, too. As a result of the deep supplier relationships small firms hope they can make stronger and more stable their supply chain and reduce supply shortage risk (ELLEGAARD, 2006) and they are more prepared to satisfy changing and increasing customer needs (FAWCETT et. al. 2008). As I have already mentioned the success of SMEs significantly depend on the competency and capacity of their owner. The owner has central role within the organization, the owner can make important decisions, start developments, influence the success or the decline of their company. Small firms often operate with limited capacities also in management and personal dimensions not just in finances and information technology (ANJA et. al. 2009; DYERSON et. al. 2009). Moreover, small companies are greatly influenced by the external changes in economy, government, policy, socio-culture and technology (HASHIM, 2007). All these limits influence the possible application of supply chain management.

JITESH and DESHMUKH (2008) collected some characteristics of SMEs and the reasons to choose SCM that is introduced in Table 1.
Table 1: Characteristics of SMEs and reasons to choose SCM.

$\begin{array}{ll}\text { 1. Flat structure } & \text { It is easier to implement and manage change. } \\ \text { Leaders can decide independently regarding the } \\ \text { development of supply chain metrics, ways of } \\ \text { partnerships, performance indicators, and supply } \\ \text { chain perspectives. The owner possesses the total } \\ \text { authority to make decisions. There are less ma- } \\ \text { nagement levels and employee who are totally } \\ \text { committed to the increase of business while } \\ \text { making changes is not difficult. In case of big } \\ \text { companies all these facts cannot be said. }\end{array}$

2. Ability to innovate SMEs are able to innovate and develop new products and services rapidly that reduces time and cost for the total supply chain. Small firms are usually engaged by big companies for their fundamental business characteristics. That is why SMEs use SCM as business strategy.

3. Size and flexibility SMEs are more flexible thanks to their size and less number of managerial levels contrary to large companies. Because of this small organizations can improve the competitiveness of the total supply chain.

4. Information system Nowadays many new information technologies and infrastructure help small businesses, too. Companies offer economical ERP solutions for SMEs in order to compete with the big organizations.

5. Low levels of It is easy to make decisions with increased organizational flexibility of change at any stage.

hierarchy

6. CEO involvement The top management is committed that is in operational inevitable regarding SCM as strategy.

decisions

7. Difference between The use of information technology and collaboactual demand and ration can contribute to better information sharing, forecast trust and transparency in the whole system.

\begin{tabular}{ll}
\hline 8. Frequent changes & $\begin{array}{l}\text { Good relationship, understanding with customers } \\
\text { to orders }\end{array}$ \\
& $\begin{array}{l}\text { can make planning process easier and more } \\
\text { fransparent that is one of the strength of small }\end{array}$ \\
& firms have in contrary to big ones.
\end{tabular}

\begin{tabular}{ll}
$\begin{array}{l}\text { 9. Shorter } \\
\text { manufacturing lead time }\end{array}$ & Shorter manufacturing lead time \\
\hline $\begin{array}{l}\text { 10. High staff } \\
\text { turnover }\end{array}$ & $\begin{array}{l}\text { Supply chain management make working } \\
\text { environment and culture better with simplifying } \\
\text { business functions. }\end{array}$ \\
\hline
\end{tabular}

11. Customers' special High degree of flexibility helps the supply chain demands both in effectiveness and efficiency.

Source: JITESH and DESHMUKH 2008

My third sub-objective is to gather the enablers, barriers to successful supply chain implementation and their effects on SMEs. Supply chain management can help SMEs in many ways, such as: in improving leaderships, strategy, waste reduction and procurement. SMEs can focus on collaboration. Practising SCM can contribute to the development of smaller firms in business strategy and core competence, it makes possible for the small firms to utilize their scalable competences in a cooperative network with the help of partners' assets. So supply chain management can improve the SMEs' performance in competitive market. 
Taking into consideration all the facts in connection of SME sector, the smaller companies can rely on their strengths and accomplish the best from their weaknesses. Successful implementation of SCM has many critical factors, such as risk (probability of success), method (the approach adopted to balance value and risk), and visibility in the whole supply chain network. In addition, trust on supply chain partners, the involvement of the suppliers, distribution centres and other partners, required standards and skills can be the enablers of SCM. On the other hand, among barriers of SCM implementation the following factors can be mentioned: shortage in finance; high level of demand, high intensity of competition, shortage of managerial skills, absence of frameworks to build alliances among supply chain partners, IT is considered as a function and not as part of business strategy, lack of integrated information systems, and the shortage of tools to measure the effectiveness of a supply chain alliance. Moreover, SMEs have other weaknesses like their decreased capacity for using modern machineries, less scope for division of labour, higher cost per unit of output, incapacity to meet uncertainty, unutilized by-products, and poor storage and warehousing functions (THAKKAR et. al. 2008). Others identified some other barriers: lack of skilled individuals to drive supply chain development, lack of power in the supply chain, doubts, lack of interest through the supply chain to participate, lack of trust among supply chain members, lack of knowledge, geographical distance from customers and suppliers (MEEHAN and MUIR 2008). In order to adopt SCM it is essential to find the balance between strengths and weaknesses. Their ability of innovation helps them to balance the costs and time constraints (THAKKAR et. al. 2009). As smaller companies are operated and owned independently changes can be achieved easily. Their flat organizational structure and flexibility make SMEs well positioned in accepting and implementing changes. On the other hand, the norms and the attitude of the owner can have significant impacts on SCM strategy. The good and close relationships with the customers and suppliers can contribute to successful SCM concepts' implementation (MEEHAN and MUIR 2008). It is obvious that the strengths of SMEs can identify strategic challenges and opportunities of SCM in small businesses. Additionally, SCM can provide quality and leverage benefits for the SMEs. It makes possible some improvements, like better customer service, responsiveness, clarify business strategy and core competences. SCM practices can help in reducing cost, risk, product development cycle time, waste, procurement and inventory.

Referring to my main aim that how supply chain management contributes to the success of small firms I needed to examine the concept of supply chain management, to collect the most important characteristics of SMEs compared to large ones and to gather the enablers, barriers to successful supply chain implementation and their effects on SMEs. To summarize all the above mentioned factors I would highlight the fact that a small firm is not a small-sized large company. SMEs are totally different with special features.
Because of their special features small businesses often get in disadvantageous situations against the big organizations. But on the other hand small firms have such kind of characteristics that make them essential for the economy and society at the same time. As I see supply chain management is a network with many participants involved in the chain. The participants can be manufacturer, supplier, retailer and customer, too. So the partners can connect to the supply chain directly and indirectly, too. As for the small businesses SCM is an approach that helps them to operate faster and more effectively by integrating the duties of separate partners at different levels. For SMEs to be part of a well-organized supply chain have positive and negative sides, too. Due to their small size and lower position SMEs usually cannot see the whole supply chain only a small part of it and thus they are referred to their chain partners. On the other SCM can give many potential advantages to small businesses. For SMEs collaboration within the supply chain may provide an opportunity to share risk that can be a good tool to improve their performance. Partnership with large, more experienced companies carry the potential for organizational learning that can stimulate the operation of small ones. Finally, in my opinion collaboration makes it easier for the members of the SMEs sector to access certain resources that are becoming more and more important today.

\section{REFERENCES}

Acs, Z. J., - Audretsch, D. B. (1991): Innovation and technological change: An international comparison. Ann Arbor: University of Michigan Press.

ADB Asian Development Bank (2009): Enterprises in Asia: Fostering dynamism in SMEs: Key indicators for Asia and the Pacific special chapter.

Akkermans, H. - Bogerd, P. -Vos, B. (1999): Virtuous and vicious cycles on the road towards international supply chain management. International Journal of Operations \& Production Management, Vol. 19 Nos. 5/6, pp. 565-81.

Anja, S. - Thomas, B. - Sascha, K. (2009): International entrepreneurship: Towards a theory of SME Internationalization. Journal of International Business and Economics, 9 (1), pp. 1 - 12.

APO Asian Productivity Organization (2002): Asian cases on supply chain management for SMEs. Report of the Symposium on Supply Chain Management for Small and Medium Enterprises. 11 - 14 December 2001. Taipei, Republic of China.

Aragon-Correa, J. A. - Hurtado-Torres, N. - Sharma, S. Garcia-Morales, V. J. (2008): Environmental strategy and performance in small firms: A resource-based perspective. Journal of Environmental Management, 86 (1), pp. 88 103. 
Arend, R.J. - Winser, J.D. (2004): Small business and supply chain management: is there a fit? Journal of Business Venturing, Vol. 20, pp. 403-36.

Basher, V. (2010): Vendor selection and quota allocation by using fuzzy topics and linear programming. Master of Engineering in Production Engineering. University of Delhi, India.

Baymout, M. (2015): Supply Chain Management for Small and Medium Size Enterprises. International Journal of Advancements in Research and and Technology, Volume 4, Issue 5.

Bidgoli, H. (2010): The handbook of technology management: Supply chain management, marketing and advertising, and global management: Volume 2. United States of America, New Jersey: John Wiley and Sons.

Chandra, K., - Kumar, S. (2000): Supply chain management in theory and practice: A passing fad or a fundamental change? Industial Management \& Data System, 100 (3), pp. 100 - 113.

Chow, W. S., Madu, C. N, Kuei, C-H., Lu, M. H., Lin, C., \& Tseng. H. (2008): Supply chain management in the US and Taiwan: An empirical study. The International Journal of Management Science, 36, pp. 665 - 679.

Coviello, N.E. - McAuley, A. (1999): Internationalization and the smaller firm: a review of contemporary empirical research. Management International Review, Vol. 39 No. 3, pp. 223-56.

Dangayach, G.S. - Deshmukh, S.G. (2001): Manufacturing strategy - literature review and some issues. International Journal of Operations and Production Management, Vol. 21 No. 7, pp. 884-932.

Dyerson, R. - Harindranath, G. - Barnes, D. (2009): National survey of SMEs use of it in four sectors. The Electronic Journal Information Systems Evaluation, 12 (1), pp. 39 - 50.

Ebrahim, N. A. - Ahmed, S. - Taha, Z. (2008): R\&D networking and value creation in SMEs. Department of Engineering Design and Manufacture, Faculty of Engineering, University of Malaya, Kuala Lumpur.

Ellegaard, C. (2006): Small company purchasing: A research agenda. Journal of Purchasing \& Supply Management, 12, pp. $272-283$.

Fawcett, S. E. - Magnan, G. M. - Mccarter, M. W. (2008): Benefits, barriers, and bridges to effective supply chain management. Supply Chain Management: An International Journal, 13 (1), pp. 35 - 48.

Gourova, E. (2010): Knowledge management strategy for small and medium enterprises. Proceedings of the International Conference on Applied Computer Science, pp. 639-648.
Gunasekaran, A. - Ngai, E.W.T. (2003): The successful management of a small logistics company. International Journal of Physical Distribution and Logistics Management, Vol. 33 No. 9, pp. 825-42.

Handfield, R.B. - Nichols, E.L. (1999): Introduction to Supply Chain Management. Prentice Hall, Upper Saddle River, NJ, p. 2.

Hashim, M. K. (2007): SMEs in Malaysia: A brief handbook. Malaysia: August Publishing Sdn. Bhd.

Hong, P. - Jeong, J. (2006): Supply chain management practices of SMEs: From a business growth perspective. Journal Enterprise Information Management, 19 (3), pp. $292-302$.

Jitesh, J. T. - Deshmukh, S. G. (2008): Supply chain management in SMEs: Development of constructs and propositions. Asia Pacific Journal of Marketing and Logistics, ResearchGate. 2008. January.

Ketchen, D. J. Jr., Rebarick, W., Hult, G. T. M., \& Meyer, D. (2008): Best value supply chains: A key competitive weapon for the 21st century. Business Horizons, 51, pp. 235 - 243.

Koh, S. C. L, Demirbag, M., Bayraktar, E., Tatoglu, E., \& Zaim, S. (2007): The impact of supply chain management practices on performance of SMEs. Industrial Management \& Data Systems, 107(1), pp. 103 - 124.

Lagrosen, S. (2005): Customer involvement in new product development: A relationship marketing perspective. European Journal of Innovation Management, 8 (4), pp. 424 - 436.

Lazarica, M. (2009): The virtual enterprise - Opportunity for SMEs in the digital economy. Annals, Economic Science Series, XV, pp. $501-505$.

Levy, M. - Powell, P. - Yetton, P. (2001): SMEs: Aligning is and the strategic context. Journal of Information Technology, 16 (3), pp. 133 - 144.

Li, S. - Subba Rao, S. - Ragu-Nathan, T. S. - Ragu-Nathan, B. (2005): Development and validation of a measurement instrument for studying supply chain management practices. Journal of Operations Management, 23, pp. 618 - 641.

Lummus, R. R., - Vokurka, R. J. (1999): Defining supply chain management: A historical perspective and practical guidelines. Industial Management \& Data Systems, 99 (1), pp. $11-17$.

Meehan, J., - Muir, L. (2008): SCM in Merseyside SMEs: Benefits and barriers. The TQM Journal , 20 (3), pp. 223 - 232.

Melnyk, S. A. - Lummus, R. R. - Vokurka, R. J. - Burns, L. J. - Sandor, J. (2009): Mapping the future of supply 
chain management: A Delphi study. International Journal of Production Research, 47 (16), pp. 4629 - 4653.

Meehan, J. - Muir, L. (2008): SCM in Merseyside SMEs: Benefits and barriers. The TQM Journal , 20 (3), pp. 223 -232 .

Mentzer, J. T. - Dewitt, W., - Keebler, J. S. (2001): Defining supply chain management. Journal of Business Logistics, 22 (2), pp.1-25.

Mohanty, R. P. - Deshmukh, S. G. (2005): Supply chain management: Theories and practices. Delhi: Biztantra Publication.

Mudambi, R. - Schrunder, C. P. - Mongar, A. (2004): How co-operative is co-operative purchasing in smaller firms? Evidence from UK engineering SMEs. Long Range Planing, 37, pp. $85-102$.

O'Gorman, C. (2001): The sustainability of growth in smalland medium-sized enterprises. International Journal of Entrepreneurial Behaviour and Research, Vol. 7 No. 2, pp. 60-70.

Pittaway, L., - Morrissey, B. (2004): Buyer-supplier relationships in small firms: The use of social factors to manage relationships. Lancaster University Management School Working Paper.

Porter, M.E. (1985): Competitive Advantage. Free Press, New York, NY.

Quayle, M. (2003): A study of supply chain management practices in UK industrial SMEs. Supply Chain Management - An International Journal, Vol. 8 No. 1, pp. 79-86.

Richardson (1995): Logistics help for the challenged. Transporation and Distribution, Vol. 36, No. 1, pp. 36-46.

Stock, J. R., - Boyer, S. L. (2009): Developing a consensus definition of a supply chain management: A qualitative study. International Journal of Physical Distribution \& Logistics Management, 39 (8), pp. 690 - 711.

Szira, Z. (2014): The Situation of the SME Sector in Hungary. Management, Enterprise and Benchmarking - In the 21st Century. Budapest, Hungary, pp. 107 - 118.

Tan, K. C. (2002): Supply chain management: Practices, concerns, and performance issues. Journal of Supply Chain Management, 38 (1), pp. 42 - 53.

Thakkar, J. - Kanda, A. - Deshmukh, S. G. (2009): Supply chain management for SMEs: A research introduction. Management Research News, 32 (10), pp. 970 - 993.
Thakkar, J. - Kanda, A. - Deshmukh, S., (2008): Supply chain management in SMEs: development of constructs and propositions. Asia Pacific, Journal of Marketing and Logistics Vol. 20 No. 1, pp. 97-131.

Thoo A. C. - Abu B. A. H. - Amran R. - Rohaizat B. (2012): Adoption of supply chain management in SMEs. Elsevier Ltd, JIBES University, Jakarta, International Congress on Interdisciplinary Business and Social Science 2012. 
